\title{
Analisis Perubahan Kawasan Mangrove Berdasarkan Interpretasi Data Spasial Di Tn. Sembilang, Pantai Timur Sumatera, Banyuasin, Sumsel
}

\author{
Yetty Hastiana ${ }^{1}$, Fachrurrozie Sjarkowi ${ }^{2}$, Dinar Dwi Anugrah Putranto ${ }^{3}$, Rasjid Ridho ${ }^{4}$ \\ Alamat: Universitas Muhammadiyah Palembang, Jln. Jend. A.Yani 13 Ulu Palembang \\ e_mail: yet hasti@yahoo.com; dwianugerah@yahoo.co.id; rasyid_mr@yahoo.com \\ 1. Staf Pengajar pada Universitas Muhammadiyah Palembang, Palembang, Indonesia. \\ 2. Guru Besar pada Fakultas Pertanian Universitas Sriwijaya, Palembang, Indonesia. \\ 3. Staf Pengajar pada Fakultas Teknik Unsri, Palembang, Indonesia. \\ 4. Staf Pengajar pada Fakultas MIPA Unsri, Palembang, Indonesia.
}

\begin{abstract}
Due to the importance of mangrove ecosystem role to coastal area stability, study and research on mangrove ecosystem is interesting. Several study forms can be performed including by sightseeing and predicting degradation and change of mangrove conservation area during certain time. Result of prediction and analysis can be used by decision maker to state the priority of area protection. As intial step in management analysis for mangrove area ecosystem in Pasut area , TN. Sembilang Pantai Timur Sumatera, Banyuasin, SumSel,interpretation and identification can be performed during six years since it was stated as National park in 2003. Several techniques can be used for analyzing the ecosystem changes, one of these is by using remote sensing. In this research, remote sensing approach by landsat profile data from 2003 and 2009. The use of landsat data sequentially was aimed to interpret and identify changes in mangrove area during the time. Result of research showed that during six years there was changes and degradation mangrove ecosystem to be non mangrove of $14,57 \%$. This analysis hopely can be used as reference to apply wisdom and strategy of coastal area management . Analysis and strategic approach is become part of area optimation to reduce environmental pressures including biodiversity protection, coastal area protection also small islands from global climate change effect.
\end{abstract}

Keywords: Spatial Analysis, Mangrove Ecosystem, Remote Sensing, TN. Sembilang SumSel. 